\title{
XII CONGRESSO DA ASSOCIAÇÃO BRASILEIRA DE ESTUDOS DO QUATERNÁRIO - 2009
}

\author{
Déborah de Oliveira *
}

No XI Congresso da ABEQUA, realizado na cidade de Belém do Pará, em 2007, foi apresentada uma proposta por colegas argentinos de sediar o XII Congresso da ABEQUA na cidade de La Plata, em conjunto com o IV Congresso Argentino de Quaternário e Geomorfologia e a II Reunião sobre o Quaternário da América do Sul. A proposta foi aceita e este foi o primeiro Congresso da ABEQUA realizado fora do Brasil.

Os eventos conjuntos contaram com a participação de pesquisadores ingleses, franceses, dentre outros, além da grande maioria de argentinos e brasileiros.

O congresso foi dividido em simpósios, que são os eixos temáticos, a seguir:

\section{1- Paleosuperfícies em Regiões Cratônicas e Evolução da Paisagem de Longo Prazo.}

\section{2- Grandes Rios da América do Sul}

3- Ambientes costeiros e de plataforma da América do Sul

\section{4- Paleoclimas da América do Sul}

5- Estudos Multidisciplinares em Arqueologia

6- Geologia e Geomorfologia de Planícies

7- Tectônica do Quaternário

8- Pedologia, Paleopedologia e seu Significado Paleoclimático

9- Desertificação e Ocupações Humanas
Os simpósios tiveram conferências e apresentações orais, divididas em três dias, além de pôsteres, que foram apresentados numa única noite, o que comprometeu bastante a participação dos que iriam apresentar seus pôsteres, pois havia dezenas deles sendo apresentados ao mesmo tempo. Como prática do evento, a maior participação foi de pesquisadores que estudam ambientes costeiros e o trabalho de campo mais importante do evento contou também com esta temática. O campo foi realizado após o evento, da cidade de La Plata até o encontro do rio de La Plata com o oceano, em Punta Índio, onde foram visitados 15 pontos e observados terraços marinhos, hoje atravessados por grandes rios.

A participação dos congressistas foi importante. Foram enviados 422 trabalhos, que foram apresentados tanto oralmente quanto em forma de pôster.

Os trabalhos apresentados foram de qualidade muito boa, porém houve problemas de logística quanto aos horários das apresentações orais, o que impossibilitou o congressista de escolher as apresentações que queria assistir. Não havia a possibilidade de escolher as apresentações pelo horário fornecido pela organização do evento, o que impediu o congressista de se deslocar de um simpósio a outro.

O evento foi muito positivo, pois contou com a participação de pesquisadores experientes e de muitos alunos de graduação e pós-graduação, o que propiciou a troca de experiências. 
